2. Гегель Г. Лекции по истории фрилософии. URL: https://mybook.ru/author/fridrih-gegel/lekcii-po-istoriifilosofii-2/read/ (дата звернення: 05.09. 2019 р.).

3. Гудман Ф. Магические символы. М.: Золотой век, 1995. 289 с.

4. Друскин М. История зарубежной музыки. Вторая половина XIX века. М.: Музыка, 1980. Вып. 4. 528 с.

5. Каминская-Маркова Е. Н. Методология музыкознания и проблемы музыкальной культурологии. К 50 летию педагогической деятельности. Одесса: Астропринт, 2015. 532 с.

6. Лосев А. Античная музыкальная эстетика. М.: Музыка, 1960. 194 с.

7. Маркова Е. Интонационность музыкального искусства. Киев: Музична Україна, 1990. 182 с

8. Муравська О.В. Східнохристиянська парадигма європейської культури і музика XVIII-XX століть: монографрія. Одеса: Астропринт, 2017. 564 с.

9. Уилсон-Диксон Э. История христианской музыки. СПб.: Мирт, 2003. 428 с.

10. Pahlen K. Das neue Opernlexikon. München: Seehamer Verlag, 2000. 1023 S.

\title{
References
}

1. Asafiev, B. (1971). Symphonic etudes. Leningrad, Muzyka [in Russian].

2. Hegel, G. (2017). The Lectures on histories of philosophy. Retrieved from https://mybook.ru/author/fridrihgegel/lekcii-po-istorii-filosofii-2/read/

3. Gudman F. (1995). Magic symbols. Moscow: Zolotoy vjek [in Russian].

4. Druskin, M. (1980). History of foreign music. The Second half XIX age. Moscow, Muzyka [in Russian].

5. Kaminskaja-Markova, E.N. (2015). The methodology musicology and problems music culturology. To 50 years of pedagogical activity work. Odessa, Astroprint [in Ukrainian].

6. Losjev, A. (1960). Antique music esthetics. Moscow: Muzyka [in Russian].

7. Markova E. (1990). Intonation type of music art. Kyiv: Muzychna Ukrajina [in Ukrainian].

8. Muravskaja O. (2017). The east-Christian paradigm of the European culture and music XVIII-XX century: monograph. Odessa: Astroprint [in Ukraine].

9. Wilson-Dickson A. (2003). A brief history of Christian music. S.-Peterburg: Mirt [in Russian].

10. Pahlen K. (2000). Das Neue Opernlexikon. München: Seehamer Verlag [in Germany].

Стаття надійшла до редакції 11.09.2019 p. Прийнято до публікації 10.10.2019 р.

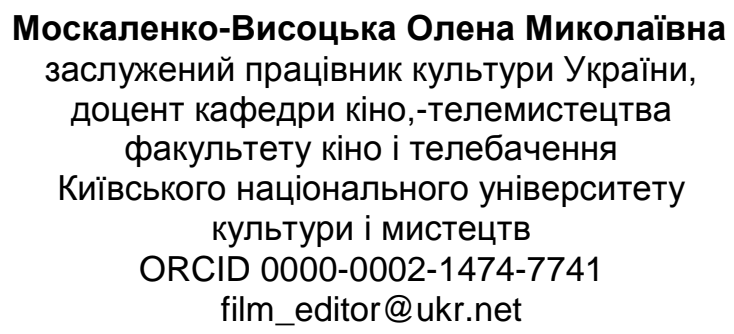

\section{ОСОБЛИВОСТІ РЕЛЕВАНТНОСТІ УКРАЇНСЬКОЇ ЕКРАНІЗАЦІЇ}

\begin{abstract}
Мета дослідження - виявлення характерних рис української екранізації в період 70-х років XX століття шляхом дослідження питань, пов'язаних з встановленням взаємозв'язку між фрільмом та літературним першоджерелом; визначення міри залежності відмінностей фільму від твору письменника, а також ступінь релевантності, відповідності книги і фільму. Методологічною основою дослідження є герменевтичні інтерпретації, що базуються на порівняльному аналізі ігрових фрільмів з літературними першоджерелами, які лягли в основу екранізацій. Предметом дослідження стали фільми "Овод" М. Мащенка, "Лісова пісня. Мавка" Ю. Іллєнка та "Чорна курка та Підземні жителі" В. Греся. Наукова новизна полягає у відкритті принципових моментів концептуальних змін в умовах перекладу літературних творів на мову кіно. На матеріалі українських екранізацій певного історичного періоду, який виявився не достатньо охоплений науковими розвідками, проведені дослідження особливостей трансформації твору з одніє мовної системи в іншу. Висновки. Визначена релевантність українських екранізацій своїм першоджерелам. Простежені змістові трансформації літературних творів, які автономізувалися в самозначущі креативні елементи емблематичних кінотворів вітчизняних режисерів. Запропоновано класифікацію видів екранізації, які умовно можна позначити як "пряма екранізація", "авторська екранізація" та "за мотивами". Встановлено, що на інтерпретацію тлумачення літературної першооснови впливають такі чинники, як особисте авторське розуміння теми та ідеї твору, вплив історичного періоду, в момент якого створюється фільм, соціальні тенденції, що відбуваються в суспільстві та активне звернення до елементів національних традицій як складових для формування естетичних запитів репіцієнтів певної доби.
\end{abstract}

Ключові слова: "пряма" екранізація; "авторська"; екранізація; фільм за мотивами; ігрове кіно.

Москаленко-Высоцкая Елена Николаевна, заслуженный работник культуры Украины, доцент кафедры кино,-телеискусства, фракультет кино и телевидения Киевского национального университета культуры и искусств

Особенности релевантности украинский экранизации

(C) Москаленко-Висоцька О. М., 2020 
Цель исследования - выявление характерных черт украинской экранизации в период 70-х годов XX века путем исследования вопросов, связанных с установлением взаимосвязи между фильмом и литературным первоисточником; определение степени зависимости различий фильма от произведения писателя, а также степень релевантности, соответствия книги и фильма. Методологической основой исследования являются герменевтические интерпретации, основанные на сравнительном анализе игровых фильмов с литературными первоисточниками, которые легли в основу экранизаций. Предметом исследования стали фильмы "Овод" М. Мащенко, "Лесная песня. Мавка" Ю. Іллєнка и "Черная курица и Подземные жители" В. Греся. Научная новизна заключается в открытии принципиальных моментов концептуальных изменений в условиях перевода литературных произведений на язык кино. На материале украинских экранизаций определенного исторического периода, который оказался недостаточно охвачен научными исследованиями, проведены исследования особенностей трансформации произведения с одной языковой системы в другую. Выводы. Определена релевантность украинских экранизаций своим первоисточникам. Прослежены смысловые трансформации литературных произведений, которые автономизировались в самозначущие креативные элементы эмблематических кинопроизведений отечественных режиссеров. Предложена классификация видов экранизации, которые условно можно обозначить как "прямая экранизация", "авторская экранизация" и "по мотивам". Установлено, что на интерпретацию толкования литературной первоосновы влияют такие фракторы, как личное авторское понимание темы и идеи произведения, влияние исторического периода, в момент которого создается фрильм, социальные тенденции, происходящие в обществе и активное обращение к элементам национальных традиций как составляющих для формирования эстетических запросов репициентов определенной эпохи.

Ключевые слова: "прямая" экранизация; "авторская" экранизация; фильм по мотивам; игровое кино.

Moskalenko-Vysotska Olena, Honored Worker of Culture of Ukraine, Associate Professor of the Department of Cinema, Telecommunications, Faculty of Cinema and Television of the Kyiv National University of Culture and Arts Features of relevance Ukrainian screening

The purpose of the article is to identify the characteristics of Ukrainian film adaptation during the period of the 70 s of the twentieth century by exploring issues related to establishing the relationship between the film and the literary source; determining the degree of dependence of the differences of the film on the work of the writer, as well as the degree of relevance, correspondence of the book and the film. The methodology of the research is hermeneutic interpretations based on a comparative analysis of fiction films with literary original sources, which formed the basis of the screen versions. The subject of the study was the films "The Gadfly" by M. Mashchenko, "Forest Song. Mavka" by Yu. Ilyenka, "Black Chicken and Underground People" by V. Gres. Scientific novelty lies in the discovery of fundamental moments of conceptual changes in the conditions of translation of literary works into the language of cinema. On the material of the Ukrainian screenings of a certain historical period, which was not sufficiently covered by scientific research, studies were conducted on the peculiarities of the transformation of a work from one language system to another. Conclusions. The relevance of Ukrainian screen versions to its primary sources has been determined. The author traces the semantic transformations of literary works that were autonomized into the self-meaning creative elements of the emblematic cinematographic works of Russian directors. A classification of types of screen versions has been proposed, which can be conventionally denoted as "direct screen version ", "author screen version" and "based on motives". It has been established that the interpretation of the literary fundamental principle interpretation is influenced by such factors as the author's personal understanding of the theme and ideas of the work, the influence of the historical period at which the film is created, social trends occurring in society and active appeal to elements of national traditions as components for the formation of aesthetic requests replicants of a certain era.

Key words: "direct" film adaptation; "author's" film adaptation; movie based on; fiction films.

Актуальність теми дослідження. Питання екранізації постійно були і залишаються предметом обговорення у колі теоретиків і практиків кіно. Прискіпливий інтерес і чимало невирішених проблем в цій галузі зумовлені складністю взаємозв'язків, які існують між літературою та кіномистецтвом, що черпає у ній теми та натхнення. Використання одним мистецтвом творчих досягнень іншого явище доволі не нове. Ще за 200 років до перших гарячих дискусій з проблем екранізацій німецький драматург, теоретик мистецтва Готгольд Ефраїм Лессінг у 1766 році в роботі "Лаокоон, чи про кордони живопису і поезії" дав фактично єдине значне дослідження найбільш загальних естетичних передумов, які відповідають на питання про можливості перекладу одного виду мистецтва в інший (7).

Від початку ери кінематографу мають місце цілком полярні точки зору на саму сутність процесу КНИГА - ФІЛЬМ. Проблематичним $€$ відсутність системного дослідження найкращих зразків української екранізації періоду 70-х, що унеможливлює ствердження, про те, що поява вказаних у цьому дослідженні фракторів, безперечно, відкриває нову сторінку української екранізації. Вітчизняні мистецтвознавці лише пунктирно торкались теоретичних питань української екранізації того періоду. Тож, у представленій роботі є можливість систематизувати основні види екранізації та характерні ознаки, на основі емблематичного аналізу низки фрільмів тих часів.

Аналіз останніх досліджень і публікацій. Питання - талановито копіювати чи відходити подалі від першооснови, та ступінь релевантності творів відносно очікування репіцієнтів - хвилювало теоретиків і творців у всіх видах мистецтва. У XX столітті про сліпе копіювання, наприклад, висловлювався відомий мистецтвознавець, письменник Ю. М. Тинянов, який стверджував, що творча і естетична проблема міститься у створенні рівноцінного художнього еквіваленту, здатного дати самостійне життя твору [13]. Мистецтвознавці сходились на тому, що не потрібно мовою одного мистецтва дослівно повторювати твір, створений мовою іншого. Проте, ця обставина не виключає, що при трансформації твору з однієї мовної системи в іншу, треба слідувати насамперед духу твору. Розмірковуючи про це, 
відомий кінорежисер С. А. Герасимов, зазначав: "Потрібен великий талант, щоб зберегти вірність автору, одночасно змусити події минулих років зазвучати сучасно" [11, 22].

Кінознавець, професор А. Вартанов, розмірковуючи над питаннями екранізації, дійшов висновку: "Трансформація літературного образу на екрані настільки складна і копітка, що потребує від кінематографрістів не лише досвіду, але й ... вміння знаходити несподівані новаторські рішення" [5, 141].

Українське кінознавство також містить чимало досліджень проблем екранізації власне українського кіно, серед них книги літературознавця О. К. Бобишкіна "Українська література на екрані" [1], доктора фрілологічних наук Л. 3. Погрібної "Твори М. Коцюбинського на екрані" [10], грунтовні роботи професора Б. С. Буряка, який досліджував питання розвитку літератури та кіномистецтва [3; 4], кінознавців О. С. Мусієнко [8; 9], Л. І. Брюховецької [2], які на прикладах українських фільмів торкалися питань екранізації. Мабуть, слід визнати, що інтенсивність пошуків в цій галузі українських режисерів висуває на перший план завдання осмислення процесу теоретичною думкою, яке стане основою даної роботи.

Метою статті є дослідження ігрових фрільмів, створених на основі літературних творів, українськими кіномитцями в період 70-х років та систематизація питань, пов'язаних зі встановленням взаємозв'язку фрільму і літературного першоджерела; визначення ступеня залежності критеріїв оцінки режисера від твору письменника, а також визначення умовних видів екранізації.

Виклад основного матеріалу. При всій схематичності поділу екранізації на різні види, при тому, що розподіл у мистецтві на види і роди має досить умовний характер, все ж, сама практика розвитку кінематографра дає підстави зробити таку спробу. На нашу думку в екранізації можливо виділити три основні види.

Перший з них умовно можна назвати - пряма екранізація. ІІЇ характерною рисою є надзвичайно бережливе ставлення до змісту першоджерела. Ступінь відступу від нього тут вкрай незначний. Режисер, зазвичай, намагається в основному зберегти авторський текст, суттєво не змінює дійові особи оригіналу, слідує авторській фрабулі без суттєвих змін, тощо.

Природно, що під час оцінювання творів "прямої" екранізації, глядач обов'язково порівнює фрільм з першоджерелом. Це абсолютно об'єктивний процес, адже свідомість зберігає у своїй пам'яті образи прочитаного літературного твору, і цей відбиток у пам'яті супроводжує глядача як власний паралельний монтаж. Використовуючи суто специфічні засоби виразності - зоровий та звуковий ряд, колір та ритм - кіно відтворює художні образи та думки, автором яких є письменник.

В українській екранізації 70-х років серед інших фільмів прямою екранізацією можна вважати стрічку "Овод" режисера Миколи Мащенка. Звернення до однойменної книги Етель Ліліан Войнич у радянському кіно вже відбувалось у 1955 році з Олегом Стриженовим у головній ролі, коли роман був екранізований радянським режисером О. Файнциммером.

Повторна екранізація - нове явище в українському кіно, що проявилось саме в 70-ті роки. Як і в першому, так і в другому випадках, трактовка основної ідеї та образів роману були перенесені на екран без змін. Фабула не змінилася, мотивації вчинків головних героїв не зазнали будь-яких перетворень, революційний дух твору був суголосний ідеологічним критеріям радянського суспільства. М. Мащенко, продовжуючи розвивати свій творчий принцип - все підпорядковано головному герою - залишив другорядних героїв без яскравих індивідуальних рис. Послабивши психологічну розробку оточення головного героя, режисер тим самим збіднив загальний замисел фільму, адже поза достовірного фону тяжко повірити і зрозуміти мотивацію багатьох вчинків героїв. У цілому ж, в екранізації "Овод", у порівнянні з літературним першоджерелом, тема роману і жанр були збережені, художні образи не зазнали особливих змін, що впевнено відносить фільм до виду "прямої екранізації".

Слід також звернути увагу на те, що фільм "Овод" створено у телевізійному форматі. Це один з принципових моментів розвитку екранізації в українському кінематографрі 70-х років. Український кінокритик О. С. Мусієнко зазначала: "Нові перспективи для екранізації, для більш повного, яскравого прочитання літературного твору несе телебачення...На телевізійному екрані кадр може довше утримуватись, ніж на кінематографічному. А це сприяє більш повному "прочитанню" малюнка" [9, 4]. Поява телевізійної екранізації ознаменувалась саме в зазначений період і характеризувалась багатьма фільмами, серед яких найвідомішими були багатосерійні "Як гартувалася сталь" М. Мащенка, "Бумбараш" М. Рашеєва та А. Народицького, "Три мушкетери" Г. Юнгвальд-Хількевича та ін.

Другий вид екранізації можна умовно позначити як "авторська екранізація". Треба зазначити про множинність тлумачень цього поняття. Деякі пошуковці будь-який талановитий фільм схильні вважати авторським. Інші застосовують його для позначення деякої домінанти суб'єктивного погляду на концептуальному рівні. У трактуванні кінознавця, культуролога В. Дьоміна авторська концепція - це "та концепція, те реально нове, що привноситься режисером у відповідь на дозрівшу суспільну потребу" [6, 66]. На нашу думку "авторська екранізація" представляє собою зміну усталеного трактування характерів літературного твору, допускає видозміну сюжетної лінії, жанрове та стилістичне зміщення, значні купюри текстів, що, в результаті, позначається на характері конфллікту та його вирішенні, але залишає дух автора першоджерела. 
Поняття "авторський" нами вибрано в силу того, що в даному випадку мова йде про наявність двох авторських начал: з одного боку - письменника, з іншого - режисера. Вони ніби стають співавторами, але домінуючою постаттю стає режисер. У процесі такої взаємодії повинен з'явитися новий твір, який в певній мірі розширює нашу уяву про людей та час, описаний автором першоджерела. Якщо в результаті екранізації народжується нова художня цінність, нова поетика, то природно зникає необхідність порівняння КНИГА-ФІЛЬМ, а, отже, така авторська екранізація стверджується як самодостатній твір і набуває незалежний від оригінала статус.

Дещо інший стан виникає у зв'язку з випадками не зовсім вдалої екранізації. Будь-яка невдача, і в мистецтві зокрема, потребує пошуку причин, що її зумовили, ось чому в такому разі виникає доцільність звернення до першоджерела. В цьому випадку слід з'ясувати наскільки твір письменника давав привід для внесення концептуальних коректив, наскільки значимі нові ідеї режисера в порівнянні зі світом ідей автора книги, наскільки сумісними виявилися світосприйняття двох митців, наскільки режисер був послідовним у втіленні свого замислу. Врешті-решт, необхідно з'ясувати чим викликані відхилення від першоджерела - бажанням переосмислити і доповнити, чи нездатністю зрозуміти і зберегти. Без звернення до першоджерела знайти відповіді на ці запитання не можливо. Як приклад авторської екранізації розглянемо фрільм Юрія Іллєнка "Лісова пісня. Мавка", створеного за однойменною драмою-феєрією Лесі Українки "Лісова пісня" (Київська кіностудія ім. О. П. Довженка, 1980 р.).

Режисер відчув органіку літературного твору, яка ніби створена для кінематографу. Тільки кіномистецтву під силу втілити з усією повнотою ту природність та феєричність, без якої цей твір втратив би свій глибокий сенс та внутрішню єдність. До постановки "Лісової пісні" український кінематограф вже звертався. Так у 1961 році на кіностудії ім. Олександра Довженка режисер Віктор Івченко зробив ігровий повнометражний фільм "Лісова пісня" з Раїсою Недашківською у ролі Мавки, а згодом у 1976 році на студії "Київнаукфрільм" режисер Алла Грачова створила однойменний анімаційний фрільм.

Юрій Іллєнко до цієї екранізації йшов довго і наполегливо, бажаючи втілити особистісні відчуття і розуміння казки-феєрії. Саме тому, що нова екранізація багато в чому несподівана, по-своєму трактує відомий зміст, її можна назвати "авторською". Опосередковано цю думку підтверджує відомий український кінознавець О. М. Мусієнко, говорячи про творчість Ю. Г. Іллєнка: "Ю. Іллєнко в своїх фрільмах ніколи не відображав повсякденну реальність. Він творив свій авторський кіносвіт, далекий від класичної гармонійності, сповнений неочікуваного перетину світла і тіні, зміщення верху і низу, змішання барв і тонів на грані доброго смаку" $[8,2]$.

Беручись за екранізацію твору Лесі Українки, Ю. Іллєнко вважав, що загальноприйнятний погляд на образи головних героїв п'єси не здається йому виключно правильним. Мавка на його думку, є не тільки ліричним, беззахисним юним створінням, а натурой пристрастною, дієвою. "Мавка, у ролі якої виступила Людмила Єфіменко, не ідеалізована під штамповий типаж зрадженої невинної жертви. Нi, вона могутня та холоднокровна у своїй нематеріальній природі, і її несусвітня любов, урешті-решт, приносить руїну традиційному світові людей, які нездатні піднятися понад свої слабкості до рівня її духовної самопосвяти" підтверджував цю думку режисера український канадський літературознавець Марко-Роберт Стех [12].

Принципово новий підхід до образу головної героїні, звичайно ж, не міг не позначитись на основній ідеї твору. Ознакою суб'єктивного прочитання "Лісової пісні" є режисерське ототожнення головної героїні п'єси з особистістю поетеси. Режисер намагався підкреслити подібність їх духовних якостей - самостійність характеру, чистоту і віру, відкритість до людей та здатність до самопожертви. Таке трактування зумовлене виказаною не один раз Лесею Українкою думкою про те, що доля Мавки була вистраждана нею в житті. Можливо тому, в Іллєнківському образі Мавки, ми не побачимо юної, мрійливої, трепетної дівчини. Навпаки, перед нами цілеспрямована молода жінка, яка знає життя і може відстоювати свої інтереси не підкорюючись обставинам, а з власних міркувань. I, хоча сюжетна канва літературного джерела концептуально не змінена, та мотивація вчинків головної героїні вибудовується згідно з новим режисерським трактуванням образу, тотожнім з його розумінням образів у фрілософрському аспекті.

Перед зйомками режисер маніфестував: "У драмі мене цікавить насамперед моральнофрілософський аспект... Стихія людей і стихія лісу в нашому фрільмі мають бути злиті, природа являтиме собою середовище драматичних «аргументів» поведінки персонажів" [2, 53].

Вдаючись до власного трактування інших образів п'єси, режисер надав персонажам своє уявлення про їх сутність - це і чорт Куць, і Той, хто в скалі сидить та ін. Характерна в цьому плані розробка сцени смерті дядька Лева. В п'єсі немає такого епізоду, але в авторській екранізації запропоновано художнє розкриття суті цього персонажу, яке тільки збагачує повноту зазначеного образу, тому що авторський замисел виявився цілком суголосним основі першоджерела: дядько Лев, відчуваючи наближення смерті, прийшов до правічного Дуба. І природа в образі Лісовика допомогла йому - він "відійшов" з посмішкою на обличчі, побачивши себе в останню хвилину молодим. Далі - на тіло впав жовтий лист, потім вся земля навкруг вбралась осіннім листом - прийшла осінь. Так органічно вибудуваний душевний стан небіжчика і одночасно продумано і монтажно подано наступний часовий простір оповіді, перехід літа до осені, від однієї частини твору до іншої. Зазначимо, що основна частина фрільму вирішена в такій же манері. Замінивши слова кінематографічною дією, режисер знайшов 
рівноцінний художній еквівалент літературному першоджерелу. (Саме за це Ю. Іллєнко був нагороджений призом XIV Всесоюзного кінофестивалю у м. Вільнюсі - "За пошуки в образотворчому рішенні фрільму "Лісова пісня. Мавка").

Слід зазначити, що не все у авторській трактовці є тотожним п'єсі. Деякі режисерські тлумачення першоджерела $є$ спірними, але здебільшого в авторських екранізаціях зростає доля суб'єктивної думки режисера, що часто стає об'єктом дискусій.

Третій вид екранізацій - за мотивами. Він досить розповсюджений, бо дає можливість "виправдати" вільний злет фантазій режисерів, які скористались брендом певного літературного твору. Кінематографрічна практика надає кілька можливих модифікацій цього виду. В першому випадку - в межах одного сюжету можуть бути об'єднані декілька оповідань автора. Відбувається певна сублімація характерів кількох персонажів у один образ, а також використовуються подієві основи з різних творів автора для складання нової сюжетної конструкції. Схрещення сукупності тем і образів передбачає появу нової художньої якості, може представити світ автора значно об'ємніше та яскравіше. У такий спосіб створений фільм Михайла Іллєнка "Нісенітниця" за мотивами твору А. П. Чехова "Чоботи всмятку" (Київська кіностудія ім. О. П. Довженка, 1978 р.). У подібних випадках режисери звертаються до малих форм літератури, намагаючись у їх синтезі відкрити більш узагальнений і глибокий зміст. Також викристалізувався і дещо інший принцип екранізації за мотивами: в ньому режисер використовує один твір письменника, відмовляючись від багатьох персонажів, концентруючи увагу на якомусь одному герої, дофантазувавши його минуле і майбутнє. Буває, що режисер зі сценаристом населяють світ письменника новими персонажами, спонукаючи їх діяти в межах соціально-побутових умов, заданих автором. Така екранізація, зазвичай, найбільш віддалена від літературного першоджерела і надає постановнику повну свободу у виборі стилю і жанру.

Характерним варіантом такої екранізації можна вважати фрільм В. Греся "Чорна курка або Підземні мешканці" за твором письменника XIX століття Антонія Погорєльського (Київська кіностудія ім. О. П. Довженка, 1980 р.).

Фільм "Чорна курка..." - рідкісний приклад, коли екранізація твору виявляється значно суттєвіша за художніми якостями, ніж літературне першоджерело. Дещо наївна і повчальна дитяча казка розповідала про подорожі дитини в царство таїни та чарів; у автора відчувався безперечний вплив німецьких письменників-романтиків, особливо Т. Гофрмана. Режисера ж зацікавив не стільки казковий бік твору, скільки дослідження внутрішнього стану персонажу. Відхід від сюжету, поява нових персонажів і подій, кристалізація характеру, розкриття вторинних персонажів, котрі лише згадуються у книзі - все це збагатило і розширило зміст твору. В результаті в кінотворі зникла повчальність і сентиментально-риторичний стиль, притаманні казці А. Погорєльського, натомість з'явився почуттєвопсихологічний стиль.

Наукова новизна роботи полягає у виявленні процесів трансформації теми та ідеї літературного твору при перекладі на мову кіно в українській екранізації 70-х років, яка вийшла за межі, власне української літератури. Вперше наукові дослідження підтвердили, що особливого значення в розвитку українського кінематографру набула в той час поява різних підходів до екранізації, які систематизовані автором за певними видами.

Висновки. Підсумовуючи, можна зазначити, що в результаті дослідження виявлено ряд характерних ознак, притаманних українській екранізації 70-х років XX століття, які мають різні міри релевантності в системі КНИГА-ФІЛЬМ, яка залежна від ступеню режисерської інтерпретації літературного твору. Виявлено низку особливостей, притаманних зазначеному періоду: поява повторної екранізації; створення екранізації у телевізійному фрорматі; долучення народних традицій; поява симбіозу жанрів, які не передбачались першоджерелом; зміна концепції літературного твору, як прояв авторської екранізації, у відповідь на дозрівшу суспільну потребу. Досліджено систему образів, які стали основою творчого перекладу мови літературних творів на мову кіно, визначено художні засоби, які уможливили трансформацію ідей та образів. Запропоновано систематизацію видів екранізації та їх модифікацій: "пряма" екранізація, "авторська" екранізація, "за мотивами" твору.

Автор продовжить наукові розвідки у дослідженні української екранізації періоду 70-х років XX сторіччя, досліджуючи питання тематично-жанрового діапазону на основі екранізації режисерів М. Рашеєва та А. Народицького "Бумбараш", а також екранізацій, в яких яскраво прослідковуються естетичні традиції О. П. Довженка.

\section{תimepamypa}

1. Бабишкін О. Українська література на екрані : Літературно-критичний нарис. Київ: Радянський письменник, 1966. 199 с.

2. Брюховецька Л. І. Режисура Юрія Іллєнка. Кіно-театр. 2006. № 2. С. 49-55.

3. Буряк Б. С. За законами краси. Київ: Дніпро, 1967. 260 с. 1974. 359 c.

4. Буряк Б. С. Прогрес і світ прекрасного: Літературно-критичні статті. Київ: Радянський письменник, 1961. $312 \mathrm{c}$

5. Вартанов А. Образы литературы в графике и кино. Москва: Акад. наук СССР. Ин-т истории искусств,

6. Демин В. П. Позиция дебютанта. Кинопанорама. 1977. Вып. 2. С. 60-91. 
7. Лессінг Г. Лаокоон / Г. Лессінг; пер. з англ. Є. Попович. - К. : Мистецтво, 1968. - 290 с.

8. Мусієнко О. С. Кінематограф Юрія Іллєнка: всі барви світу. Культура і життя. 2006. № 37. С. 2.

9. Мусієнко О. С. Телеекранізація. Яка вона? Культура і життя. 1976. 17 жовтня. С. 4.

10. Погрібна Л. 3. Твори М. Коцюбинського на екрані. Київ : Наукова думка, 1971. 157 с.

11. Сергеев Е. Перевод с оригинала: Телеэкранизация русской литературной классики. Москва: Искусство, 1980. 200 с.

12. Стех М-Р. Фільм "Лісова пісня. Мавка" - неповторна творча візія Юрія Іллєнка // електрон. вид. Zik.ua. 05.03.2018. URI: https://www.zik.ua/news/2018/03/05/marko_r_steh_film_lisova_pisnya_mavka_svoierid a_nepovtorna_tvorcha_1278723 (дата звернення: 10.08.2019).

13. Тынянов Ю. Поэтика. История литературы. Кино. Москва: Наука, 1977. 575 с.

\title{
References
}

1. Babishkin, O.K. (1966). Ukrainian Literature on Screen: a Literary Critical Essay. Kyiv : Radjansjkyj pysjmennyk [in Ukrainian].

2. Briukhovetska, L.I. (2006). Directed by Yuri llenka. Kino-Teatr, 2, 49-55 [in Ukrainian].

3. Buryak, B.S. (1967). By the laws of beauty. Kyiv : Dnipro [in Ukrainian].

4. Buryak, B.S. (1974). Progress and the world of the beautiful: Literary-critical articles. Kyiv: Radjansjkyj pysjmennyk [in Ukrainian].

5. Vartanov, A.S. (1961). Images of literature in graphics and cinema. Moscow: Akad. Nauk SSSR. Institut istorii iskusstv [in Russian].

Russian].

6. Demin, V.P. (1977). Position of a debutant, Cinema Panorama. (issue 2), (pp. 60-81). Moscow : Iskusstvo [in

7. Lessing, G. (2010). Laocoon. (E. Popovych, Trans). Kyiv: Mystectvo [in Ukrainian].

Ukrainian]

8. Musienko, O.S. (2006). Cinema of Yuri llenka: all the colors of the world. Kul'tura i zhyttja, 37, 2 [in

9. Musienko, O.S. (1976). Television Version of the Book adaptation. What is She Like? Kul'tura i zhyttja, 17 October, 4 [in Ukrainian].

10. Pogrebna, L.Z. (1971).Works by M. Kotsyubynsky on the screen. Academy of Sciences of the Ukrainian SSR, Institute of Art Studies, Folklore and Ethnography named after M.T. Rylsky. A. A. Romitsyn (Ed.). Kyiv : Naukova dumka [in Ukrainian].

11. Sergeev, E. (1980). Translation from the original: Television Version of the Book of Russian literary classics. Moscow : Iskusstvo [in Russian].

12. Stech, M-R. (2018). The film "Forest Song. Mavka" - unique creative art by Yuriya Illnka. Zik.ua, March, $3^{\text {rd }}$. Retrieved from https://www.zik.ua/news/2018/03/05/marko_r_steh_film_lisova_pisnya_mavka [in Ukrainian].

13. Tynyanov, Yu.N. (1977). Poetics. History of literature. Movie. Moscow : Nauka [in Russian].

Стаття надійшла до редакції 17.10.2019 р. Прийнято до публікації 20.11.2019 p.

УДК 7.03’06-044.247(=161.2): 784.092(100)

Дружинець Маріанна Ігорівна
викладач кафредри естрадного співу
Київської муніципальної академії
естрадного та циркового мистецтв,
здобувач Національної академії керівних
кадрів культури і мистецтв
ORCID 0000-0003-2843-8138
marianna.druzhinec@gmail.com

\section{МІЖНАРОДНИЙ ПІСЕННИЙ КОНКУРС ЄВРОБАЧЕННЯ ЯК ВАЖЛИВИЙ ЕТАП ІНТЕГРАЦІЇ УКРАЇНСЬКОЇ КУЛЬТУРИ}

\begin{abstract}
Мета статті - розглянути основні тенденції і перспективи розвитку пісенного конкурсу Євробачення в медіа-просторі України; розкрити історію та специфіку конкурсу, історію тріумфів, правила участі та можливості проекту, специфіку та функціонування, показавши їх роль в європеїзації та євроінтеграції української культури. Методологія дослідження полягає в застосуванні компаративного, історико-логічного, аналітичного методів. Зазначений методологічний підхід дозволяє розкрити та піддати аналізу пісенний конкурс, що транслювався на українському каналі. Наукова новизна. Вперше у цій статті намагалися висвітлити специфіку та основні тенденції пісенного конкурсу Євробачення, розглянути його як шоу, як фактор європеїзації та євроінтеграції української культури. Проте недостатня розробленість в науці проблеми робить деякі положення дискусійними, розв'язання яких є важливим для сучасного культурного життя. Висновки. Конкурс Євробачення дає можливість нашим артистам нести свою творчість в Європу, у світ, тим самим інтегрувати українську культуру. Цей конкурс $є$ стимулом для українських артистів, які, перш ніж виходити на світовий ринок у конкурсі Євробачення, - європеїзують свою творчість, роблять якісний європейський продукт світового рівня, не втрачаючи при цьому кодовості української нації та культури. Міжнародний пісенний конкурс Євробачення - високий ступінь інтеграції України у світову культуру масового зразка.
\end{abstract}

(С) Дружинець М. І., 2020 